\title{
NEW PLANTATION MORATORIUM POLICY AND SMALLHOLDERS PALM OIL REJUVENATION FOR INCREASING PRODUCTIVITY OF INDONESIAN PALM OIL
}

\author{
Arif Imam Suroso ${ }^{*}$, Alm. Iyung Pahan ${ }^{* * *}$, and Syti Sarah Maesaroh $\left.{ }^{* * *}\right)$ \\ *) School of Business, IPB University \\ Jl. Raya Pajajaran Kampus IPB Baranangsiang, Bogor 16129, Indonesia \\ **) DMI Consulting Firm \\ Plasa Sentral 9th Floor \#915 Sudirman Kav. 47, Jakarta 12930, Indonesia \\ **) Business Digital, Universitas Pendidikan Indonesia \\ Jl.Dadaha No18 Kota Tasikmalaya, Tawang Kota Tasikmalaya 46115, Indonesia
}

\begin{abstract}
Palm oil is one of the plantation sub-sectors that plays an important role in the Indonesian economy. Smallholder plantation with an area of more than $40 \%$ has a significant role in the development of this industry. Low productivity becomes the main problem on -in smallholder plantation. Low productivity of smallholder plantation is mainly due to the inappropriate of plant genetic material. Genetic improvement for increased productivity can be done either through new planting (extensification) and rejuvenation (intensification). Extensification constrained Presidential Instruction 10/2011 while the intensification constrained by funding issues of rejuvenation. This research conducts a literature review, in-depth interview and questionnaire method to collect opinions from the experts and practitioners. Analytical Network Process (ANP) is used to analyze the data. The results showed that the factors which influenced in this study were policy environment $(41.29 \%)$, policy stakeholder $(35.72 \%)$, and public policy $(23.00 \%)$. The moratorium policy has not been able to improve Indonesia's forest governance. This policy precludes opportunities for economic growth for the palm oil industry. The rejuvenation of the smallholder is constrained by funding problems. Access to credit- constrained aspects of land legality. Extensification barriers and intensification of smallholders threaten the sustainability of national palm oil production. Plant genetic improvements, improved legality, and law enforcement of moratorium policies are required to increase the productivity of smallholder plantations.
\end{abstract}

Keywords: moratorium, productivity, public policy, palm oil, smallholders

\begin{abstract}
Abstrak: Minyak kelapa sawit diakui sebagai salah satu sub sektor perkebunan yang mempunyai peran penting dalam perekonomian Indonesia. Perkebunan rakyat dengan total areal lebih dari $40 \%$ memiliki peran signifikan dalam pengembangan industri. Rendahnya produktivitas menjadi permasalahan utama pada perkebunan rakyat. Rendahnya produktivitas pada perkebunan rakyat terutama disebabkan oleh penggunaan genetik bahan tanaman yang kurang tepat. Perbaikan genetik bahan tanaman untuk peningkatan produktivitas dapat dilakukan baik pada saat penanaman pada areal baru (ekstensifikasi) maupun pada saat peremajaan (intensifikasi). Esktensifikasi terkendala dengan berlakunya Inpres No 10 tahun 2011 sedangkan intensifikasi terkendala masalah pendanaan peremajaan. Tujuan penelitian ini yaitu untuk menganalisis implementasi kebijakan moratorium dan peremajaan sawit rakyat dalam peningkatan produktivitas minyak sawit. Penelitian ini menggunakan review literatur, wawancara mendalam, dan kuesioner untuk mendapatkan pendapat bersama para ahli. Analisa Metode analisis data menggunakan Analytical Network Process (ANP). Hasil penelitian menunjukkan bahwa faktor yang berpengaruh tehadap peningkatan produktivitas yaitu lingkungan kebijakan (41.29\%), pemangku kepentingan (35.72\%), dan kebijakan publik (23.00\%). Kebijakan moratorium belum dapat memperbaiki tata kelola hutan Indonesia. Kebijakan ini justru menutup peluang pertumbuhan ekonomi untuk industri kelapa sawit. Peremajaan perkebunan rakyat terkendala masalah pendanaan. Lemahnya aspek legalitas menghambat akses pekebun terhadap pendanaan. Hambatan ekstensifikasi dan intensifikasi perkebunan rakyat mengancam keberlanjutan produksi minyak sawit nasional. Perbaikan genetik bahan tanaman, perbaikan legalitas lahan, dan penegakan hukum kebijakan moratorium diperlukan untuk meningkatkan produktivitas perkebunan rakyat.
\end{abstract}

Kata kunci: moratorium, produktivitas, kebijakan publik, kelapa sawit, perkebunan rakyat

\footnotetext{
${ }^{1}$ Corresponding author:

Email: arifimamsuroso@apps.ipb.ac.id
} 


\section{INTRODUCTION}

Palm oil becomes one of the commodities that are able tocan contribute in to the economy of Indonesia (Suroso, 2008; Pahan, 2017). Palm oil is a vegetable oil of the world whose contribution tends to increase (Bappenas, 2010). Palm oil shows the highest production efficiency if ciompared to other vegetable oils (Susila, 2004; Pahan, 2017).

The production of the palm oil of Indonesia involves three main actors namely State Large Plantation/ Perkebunan Besar Negara (PBN), Private Large Plantation/Perkebunan Besar Swasta (PBS), and Smallholder Plantation/Perkebunan Rakyat (PR). The productivity of the palm oil result varies between the production subsystems. The production subsystem which is the lowest productivity is the smallholder plantation (World Growth, 2011; Pahan, 2017). The low productivity and the quality of smallholder plantation pose the a challenge in the development of Indonesian palm oil industry (Suroso, 2008; Murdiyarso et al. 2011).

The increase of the palm oil production can be done through the extensification and the intensification (Murdiyarso et al. 2011). The extensification is done through the expansion of the plantation area, while the intensification is done by optimizing the production in the existing area. The increase of the productivity both through the extensification and the intensification is prioritized through the genetic improvement of the plant material. The extensification is done through the planting in a new area, while the intensification is done through the rejuvenation in the existing area.

The genetic improvement of the plant material through the extensification is hampered by the environmental perspective. The palm oil industry is assessed to have a negative impact on the environment (Pahan, 2017). The palm oil is claimed as the driver factor of deforestation in Indonesia (Euler et al. 2015). The barriers to the expansion of the palm oil areas are implemented by the Presidential Instruction Number 10 of 2011. The genetic improvement of the plant material in the existing area is done at the time of rejuvenation. The process of rejuvenation in the Smallholder Plantation is experiencing various problems. One of the constraints of the palm oil rejuvenation is limited access to finance (Manurung et al. 2015).
The government stipulates the Government Regulation No 24 of 2015 on the Plantation Fund Collection and the Presidential Regulation No 61 of 2015 on the Collection and Use of Fund of the Palm Oil Plantation. The channeling of funds for the rejuvenation of the smallholder plantation in Indonesia is constrained. The low absorption of funds allocated in general due to the farmers are constrained issues of legality both the land certificates as well as the certificates of the sustainability, the institutional, and the procurement of the plant material (Hutabarat, 2016). The existence of the obstacles both the extensification and the intensification on the smallholder plantations affect the production of the palm oil produced. The implementation of the moratorium policy for six years (2013-2017) is considered not able to fully address the issues of the forest governance in Indonesia (FWI, 2017). This policy inhibits the economic growth, because it threatens the sustainability of Indonesian palm oil production (Joyosemito et al. 2014).

Research related to moratorium policies and rejuvenation of oil palm plantations is important to do. Previous studies generally emphasize the discussion of one aspect of determining productivity. Through this research, productivity is comprehensively assessed in several aspects consisting of the policy, the stakeholder roles, and the policy environment. The purpose of this study is to analyze the implementation of the moratorium policy and the rejuvenation of the smallholder plantation in increasing the productivity of palm oil, and analyze the determinant factor of moratorium policy and rejuvenation of smallholder plantations.

The scope of this research includes an analysis of forest moratorium policies based on Presidential Instruction Number 10 of 2011 and rejuvenation policies on Indonesia's palm oil productivity. Analysis The analysis was carried out on the upstream (upstream and midstream) subsystem of the palm oil industry. Stakeholders involved in this study include academics, business people, government, and associations.

\section{METHODS}

This research is conducted in March-July 2017. The research includes various companies and organizations related to the plantations which spread in Jakarta, Medan, Pekanbaru, and Bogor. 
Type and source of data used in this research consist of primary data are obtained through the interviews toward the experts/respondents. Secondary data are obtained from the journals or scientific publications, books, magazines, literature, articles, internet, and other scientific writings.

The sample is determined by purposive sampling methode. Respondents consisted of academics \& researchers, business actors, government, and community represented by institutions shown in Table 1.

Table 1. Location of the Research

\begin{tabular}{ll}
\hline Description & Place \\
\hline Academics/ & Bogor Agricultural University (IPB) \\
Researcher & Medan Palm Oil Research Center (PPKS) \\
& PT. First Resources Group \\
& PT. Smart Tbk \\
& PT. Sampoerna Agro Tbk \\
Business & PT. Perkebunan Nusantara III (PTPN III \\
Actor & Holding) \\
& PT. Kharisma Pemasaran Bersama \\
& Nusantara (KPBN) \\
& PT. First Resources Group \\
Government & Agency for Funding of Palm Oil Plantation \\
& (BPDPKS) \\
& Coordinating Ministry for Economic \\
& Affairs (KKBP) \\
& Indonesian Palm Oil Society (MAKSI) \\
& Association of Indonesian Palm Oil \\
Fssociation & Farmers (APKASINDO) of Sumut \\
& Association of Indonesian Palm Oil \\
& Farmers (APKASINDO) of Riau \\
& World Resources Institute (WRI) \\
&
\end{tabular}

The policy implementation is analyzed by using the Analytic Network Process (ANP) on the three elements of the policy system (Dye, 2013). The analysis is focused on the interaction that occurred between the policy, the stakeholder roles, and the policy environment. shown in Figure 1.

ANP is a qualitative approach in the decision- making process with a general framework. ANP is a development of AHP (Analytical Hierarchy Process). In AHP, each element in the hierarchy is considered independent of the other elements. in reality, there are interdependent relationships between both elements and alternatives. ANP does not require independence between elements, so ANP can be an effective tool (Rusydiana and Devi, 2013).
The stages of analysis using ANP consist of three stages: model construction, model quantification, and results from analysis. Model construction is an attempt to arrange the complexity of the problem into the ANP framework. Through this process, the dependent relationship between factors and criteria that affect productivity can be determined. ANP allows for interaction and feedback from elements in the cluster (inner dependence) and between clusters (outer dependence) (Saaty, 2001;2004a;2004b). Model quantification is done by designing a questionnaire and conducting a survey using the pairwise comparison method. The questionnaire was intended by 14 (fourteen) expert respondents who could represent the Indonesian palm oil industry. After the consistency of each respondent is obtained, a geometric multiplication is performed to obtain the weight of each element in the cluster. The results analysis phase is carried out to analyze the priority results of the strategy. The priority results of the strategy from ANP analysis can be seen from the weight of each cluster contained in the ANP framework through data processing using Super Decision software.

Hypothesis proposed in this research is moratorium policy cannot address forest governance problems in Indonesia. Instead, this policy unfortunately affects the production of palm oil in Indonesia. The presence of a moratorium policy without law enforcement and application of sustainability principle threatens the sustainability of national palm oil production.

\section{RESULTS}

\section{Policy Element System}

The determinant factors of the palm oil productivity of Indonesia are identified through theoretical studies and previous research decomposition. The formulation of these factors is based on three variables in the successful implementation of a policy: 1) the policy; 2) the stakeholder role; and; and 3) the policy environment. The results of the determinant factor decomposition are shown in Table 2.

The policy analysis model of the three elements of the policy system shows the priority weight per each cluster and node. The priority weight of ANP output is shown in Table 3. The results show that the biggest factor influencing the analysis toward the moratorium 
poloicy analysis namely the palm oil productivity (41.29\%), the smallholder plantation (35.72\%), and the moratorium policy $(23.00 \%)$. The experts agree that the policies taken aimaimed to increase the productivity. The increased productivity is done on the smallholder plantation, because the smallholder plantation shows the lowest productivity levels.
The productivity becomes an important issue in this research, because the productivity becomes the main obstacle in the competitiveness of Indonesian palm oil production. Hudori (2017) states that the average productivity of Indonesian palm oil between 2000 to 2015 is 3.41 tons / has lower than Malaysia's average productivity of 4.28 tons/ha. The productivity of $\mathrm{CPO}$ Indonesia is also below the potential of the plant material that can reach 7-8 tons of CPO/ha (Fatah, 2013).

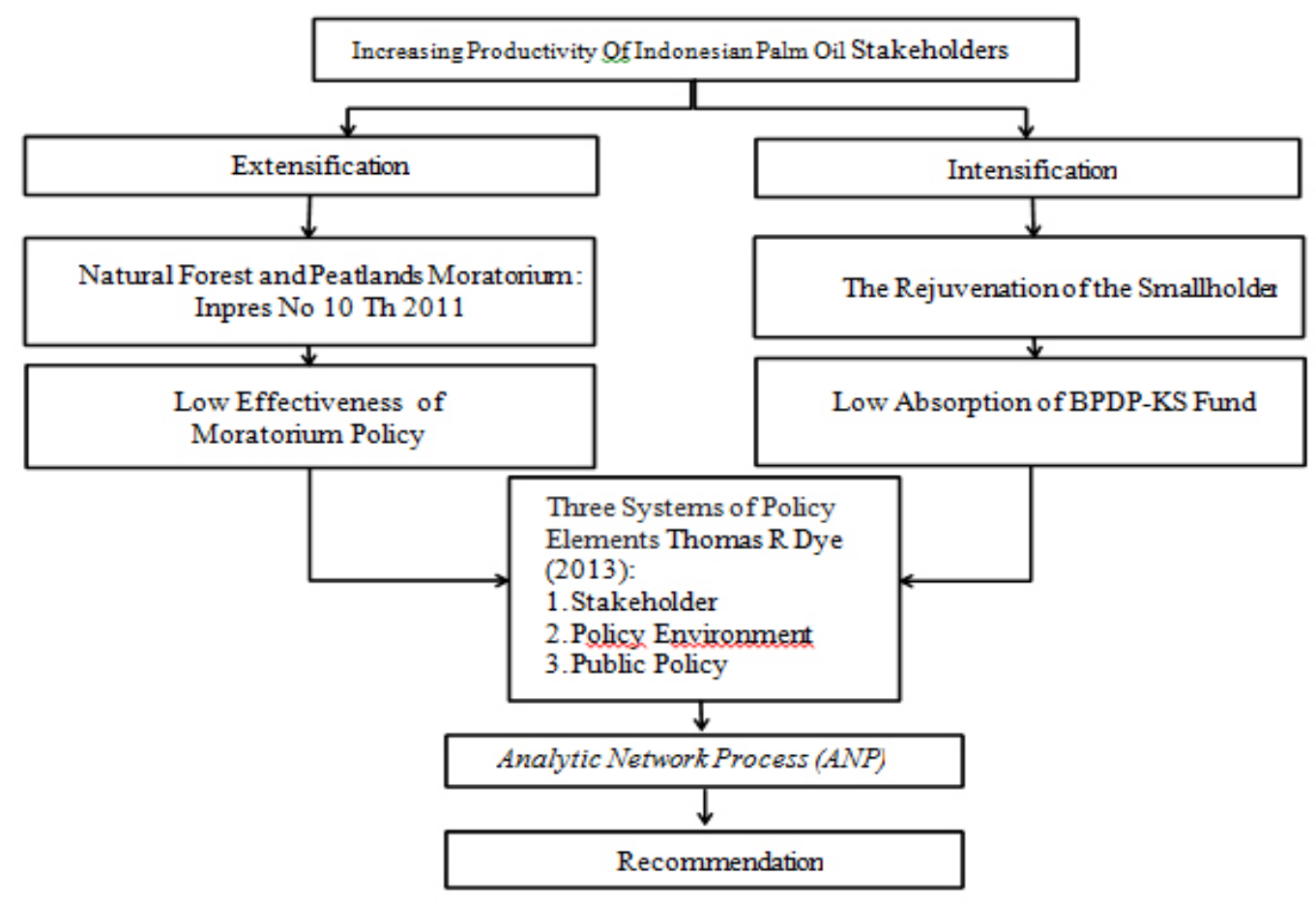

Figure 1. Research Framework

Table 2 The determinant factor decomposition of the palm oil productivity of Indonesia

\begin{tabular}{|c|c|c|}
\hline Cluster & Node & Previous Research \\
\hline \multirow{5}{*}{$\begin{array}{l}\text { Smallholder } \\
\text { Plantation } \\
\text { (Stakeholder) }\end{array}$} & Rejuvenation & $\begin{array}{l}\text { Manurung et al. (2015); Susanti et al. (2014); Nainggolan } \\
\text { (2012); IFC (2013) }\end{array}$ \\
\hline & Land Legal Aspect & Vermeulen dan Goad (2006) \\
\hline & Finance & $\begin{array}{l}\text { Vermeulen dan Goad (2006); IFC (2013); Syakir et al. (2015); } \\
\text { Alwarittzi et al. (2015) }\end{array}$ \\
\hline & Access to Fertilizer & $\begin{array}{l}\text { Hafif et al. (2014); Nainggolan (2012); Bappenas (2010); } \\
\text { Soliman et al. (2016); Hidayati et al. (2015) }\end{array}$ \\
\hline & Institutional & Pilar (2014); Alwarittzi et al. (2015); IFC (2013) \\
\hline \multirow{3}{*}{$\begin{array}{l}\text { Palm Oil } \\
\text { Productivity } \\
\text { (Policy } \\
\text { Environment) }\end{array}$} & Genetic of Plant Material & $\begin{array}{l}\text { Hidayati et al. (2015); Soliman et al. (2016); Syakir et al. } \\
\text { (2015); Nainggolan (2012); Papenfus (2011) }\end{array}$ \\
\hline & Field Technical Culture & $\begin{array}{l}\text { Vermeulen dan Goad (2006); Hidayati et al. (2015); Soliman et } \\
\text { al. (2016); Papenfus (2011) }\end{array}$ \\
\hline & Product Quality & Otieno et al. (2016); Bappenas (2010) \\
\hline \multirow{4}{*}{$\begin{array}{l}\text { Moratorium } \\
\text { Policy (Public } \\
\text { Policy) }\end{array}$} & Deforestation \& Land Conversion & Jaya et al. (2014); \\
\hline & Law Enforcement & Jaya et al. (2014); Bappenas (2010) \\
\hline & Conflict Resolution & Jaya et al. (2014); Bappenas (2010) \\
\hline & Principle of Sustainability & IFC (2013); Bappenas (2010) \\
\hline
\end{tabular}


Table 3. Priority of the determinant factor of the palm oil productivity of Indonesia

\begin{tabular}{llc}
\hline \multicolumn{1}{c}{ Cluster } & \multicolumn{1}{c}{ Node } & Weight \\
\hline Smallholder & Rejuvenation & 0.0445 \\
Plantation & Land Legal Aspect & 0.1112 \\
(Stakeholder) & Finance & 0.0873 \\
& Access to Fertilizer & 0.0328 \\
& Institutional & 0.0814 \\
& $\quad$ Sub Total & 0.3572 \\
Palm Oil & Genetic of Plant Material & 0.2211 \\
Productivity & Field Technical Culture & 0.1068 \\
(Policy & Product Quality & 0.0849 \\
Environment) & $\quad$ Sub Total & 0.4129 \\
& Deforestation \& Land & 0.0300 \\
Moratorium & Conversion & \\
Policy (Public & Law Enforcement & 0.0796 \\
Policy) & Conflict Resolution & 0.0413 \\
& Principle of Sustainability & 0.0791 \\
& $\quad$ Sub Total & 0.2300 \\
\hline
\end{tabular}

The increased productivity is prioritized by the use of the genetically certified plant material (weight of $22.11 \%$ ). Increasing of the productivity of the smallholder plantation through the genetic improvement needs to be noticed, because the proportion of the large area of the smallholder plantation in Indonesia is very large (more than 40\%). The experts assess the increase in the palm oil production in the smallholder plantation is prioritized by encouraging the use of the certified seeds. The plant genetics used by the planters are generally not the certified and unclear origin. IFC (2013) states that $78 \%$ of smallholder plantations in Indonesia use uncertified genetic material. The use of the certified seeds on the smallholder plantation is able tocan provide the greater revenues and profits from the use of the uncertified seeds.

The genetic improvement of the plant material can be done at the time of the new planting (extensification) and at the time of the rejuvenation (intensification). The existence of the moratorium policy demands the genetic improvement to increase the productivity through the rejuvenation of the smallholder plantation. The smallholder plantations according to the experts become the second priority in increasing the productivity of Indonesian palm oil. The success of the smallholder plantation in Indonesia affects the productivity the palm oil nationally. The legality aspect is a very important in the development of the smallholder plantation in Indonesia. The legality (11.12\%) is as one of the requirements for the planters to participate formally in the palm oil supply chain. The land legality plays an important role in the sustainability of the smallholder plantation business, especially for the rejuvenation. The funds needed for the rejuvenation process can not be accessed by the planters, because they do not meet the legality requirements of the land.

The intensification through the rejuvenation is hampered by the access to the rejuvenation funding. The funds provided by the government through BPDPKS can not be absorbed optimally. The absorption of the rejuvenation funds of the smallholder plantation up to 2016 only reaches $1.52 \%$. The weakness of the legality aspect especially the land tenure certificate is an important factor influencing in the smallholder plantation. The land certificate is one of the documents to be able to access the credit facilities from the government. The funds obtained can be used for the rejuvenation process and for accessing the production inputs such as certified seeds and fertilizers. The land certificates on the plantations are currently experiencing the problems such as the transfer of the certificates to other parties (Chozin et al. 2012). The low access to the credit facilities threatens the sustainability of the smallholder plantation production.

The last priority is the policy of the moratorium on the conversion of the primary natural forest and the peat. The genetic improvements through the area expansion can not be done because of this policy. The restriction of the area expansion is undertaken to improve the forestry governance in Indonesia. The fact is, the sixyear moratorium policy has not been able to overcome the problems of the forest governance (WRI, 2017). Various violations both committed by the recipient of the instruction and the general community still occur (Fandi et al. 2013). This shows that the government has no clear direction regarding the forest governance. The moratorium policy only serves as an obstacle to the growth of the palm oil industry.

The policy of the moratorium on the conversion of the natural forest and peatlands has not been matched by the improvement in the smallholder plantation. The increased productivity is not only the agronomic and technical issues of the agriculture, but also it concerns the social issues and the integrated relationships with the stakeholders. The intensification program on the smallholder plantation is still constrained. The intensification through the rejuvenation is hampered 
by the access to the rejuvenation funding. Various problems and obstacles in the improvements of the stakeholders (smallholder plantation) and the lack of the government capacity makes the moratorium policy not unoptimal.

The success of the moratorium policy according to the experts is determined by the law enforcement. The eEnvironmental law enforcement especially the forestry in Indonesia is still weak (Handayani, 2009). The violations still occur either by the private companies or by the community. The common offences offenses include not having the forest clearance license or the timber utilization permit prior tobefore the land clearing, clearing the lands in areas which are not designated as the agricultural areas, including the protected areas, not conducting the Environmental Impact Assessment (AMDAL) prior tobefore the development, operating in the deep peatlands, and clearing the land by means ofutilizing fuel (Daemeter Consulting, 2015).

The good law enforcement affects the palm oil production. The fulfillment of the sustainability criteria and principles based on the legal obedience has a positive effect on the palm oil production (Pahan, 2017). The legal obedience reflected by the fulfillment of the sustainability principles and criteria supports the increased of the palm oil production. The legal compliance of the moratorium is still considered low. This is shown by Jaya et al. (2015) which states that the area of the moratorium is decreasing. Other than that, in the period of the moratorium on the opening permit in the industrial timber plantation, the borrowing licenses and disposals of the forest areas are still carried out in the moratorium area.

\section{Policy Environment}

The fourth concensus consensus group of experts states that the genetic material of the plants is the biggest factor that affects the productivitiy with the a weight of $53.55 \%$. The field technical culture is a priority in increasing the productivity of the palm oil with the a weight of $25.87 \%$. The product quality shows the lowest priority $(20.57 \%)$ in the increased productivity of the palm oil. The priority difference among the expert groups can be seen in Figure 2.

The use of the good plant genetic material determines the production and the productivity produced. The genetics listed in the seeds or seedlings are the production means that plays an important role in the development of the palm oil productivity in Indonesia. A good technical culture in the cultivation of the palm oil plantation will be meaningless if the genetic of the plant material is not addressed. The good genetic use with the optimal technical culture provides an opportunity to improve the quality of the oil produced.

\section{Genetic of Plant Material}

The genetic is the information contained in every living cell that can be passed on to the next offspring (Hartl and Elizabeth, 1998). The facts on the ground show that the planters have difficulties in accessing the superior seeds or certified seeds. IFC (2013) states that $78 \%$ of the genetic of smallholder plantation in Indonesia used in are unclear the origin. The productivity of the palm oil plantation with the certified genetic material is very important. The standard productivity of TBS of Marihat is shown in Figure 3.

The figure shows that the productivity of the palm oil is affected by the plant age and the land suitability class. The productivity will increase gradually until a certain age then constant and decline until it reaches the age of replanting. Land suitability class can be divided based on the quality and characteristics of land which are is the most severe limiting factors. By knowing the limiting factors, it will facilitate the detailed interpretation in of land use planning. Land suitability class are is divided into S1, S2, S3, and N (Ministry of Agriculture, 2016). The S1 class (very suitable), the land does not have a significant limiting factor to sustainable use or a minor limiting factor and will not significantly reduce land productivity. Class S2 (suitable enough), the land has a limiting factor, and this limiting factor will affect its productivity so that it requires additional input (input). Class S3 (marginal suitable), the land has a severely limiting factor, and this limiting factor will affect its productivity, thus requiring more additional input than land classified as S2. Class N (not suitable), the land not recommended have a significant limiting factor to sustainable use.

Based on Figure 4, the class of S1 land provides the highest productivity value followed by S2 land class, and S3 land class. The average productivity (from the age of 3 to 25 years old) of S1 land is $27.0 \mathrm{Ton} /$ $\mathrm{Ha}, \mathrm{S} 2$ is $25.0 \mathrm{Ton} / \mathrm{Ha}$, and $\mathrm{S} 3$ is $23.0 \mathrm{Ton} / \mathrm{Ha}$. The average palm oil productivity is of 9.1 Ton TBS/ Ha (Ditjendbun, 2016). Compared with the S3 land 
standard, the smallholder plantation productivity is still very low. The low productivity in the smallholder plantation is mainly due to the improper use of the plant material genetic and the cultivation techniques that are not optimal yet.

The use of the uncertified seeds on the smallholder plantation is due to the low understanding of the planters, the distribution of fake seeds, and the institutional role that is not yet optimal. The institutional empowerment and franchising systems can increase the access of the planters to seeds. The government can play a role by conducting the training, improving the law enforcement, and improving the infrastructure.

\section{Technical Culture}

The technical culture includes the activities from the start of the area preparation, the planting, the maintenance, the fertilization, and the pest control, up to the transport of fruit to the Palm Oil Factory (PKS). The combination of the qualified genetics with the good technical culture results in the optimal productivity. Some causes of the improper application of the technical culture, namely 1) the lack of knowledge of the palm oil planters; 2) the smallholder planters access to the production inputs; and 3) the behavior of the smallholder planters (Agustira et al. 2015).

The institutional roles are important to improve the planters' understanding on of the cultivation techniques and the access to the production inputs. The government as the policy makers plays a role by improving the quality of the agricultural extension to the planters. The training can be done through the cooperation with the private companies. Increasing the role of the private sector is expected to encourage the planters to apply the good cultivation principles.

\section{Product Quality}

The quality is the end result of the plant material genetic and the technical culture that occurs in the field. The quality of TBS includes the fruit type (tenera), the fruit maturity level (the percentage of brondol), and the duration of TBS in the field (restan). The problem of the fruit quality on the smallholder plantation influences the price received by the planters from the processing companies.

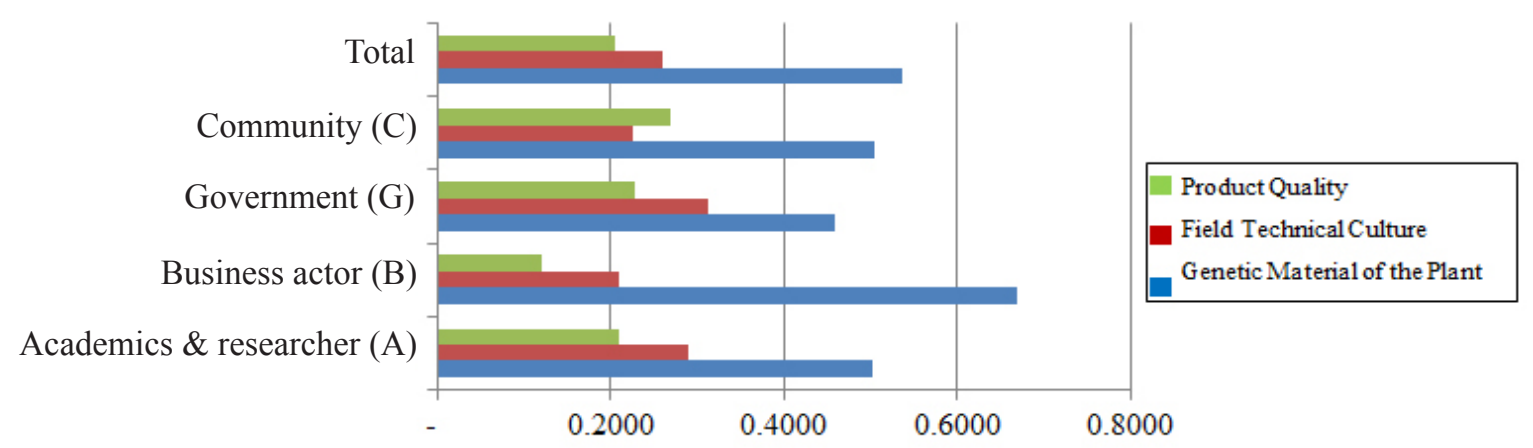

Figure 2. Policy environment priority

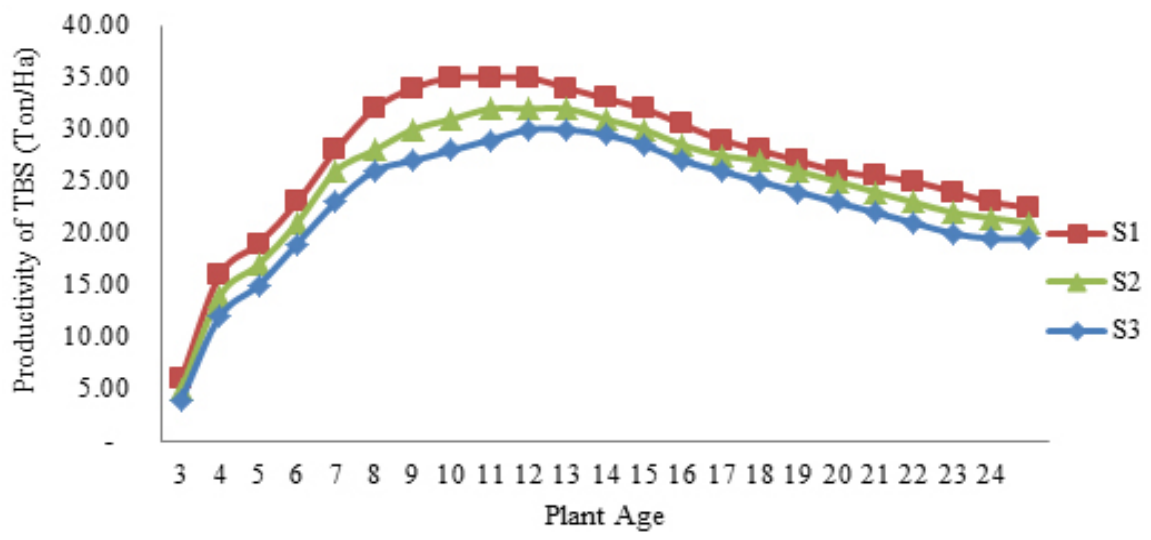

Figure 3. Productivity Standard of Marihat (PPKS, 2016) 
The institutional role becomes important in bridging the communication between the plantation companies and the planters. The institutions provide the information that is transparent in accordance with the applicable agreement. The institutional organizes the planters to be able to produce TBS that meets the predetermined quality criteria.

\section{Stakeholder Role}

The priority differences among expert groups in the community plantation cluster are shown in Figure 4. The academics and researchers the business actors, and the government state that the success of the smallholder plantation is mainly determined by the land legality aspect. While the group of the community experts states that the role of institutions is more dominant in determining the success of smallholder plantation.

In total, the consensus of the four expert groups in the stakeholder cluster states that the legal aspect of the land is the biggest factor affecting the success of the smallholder plantation with the a weight of $24.45 \%$. The third priority is the institutional with the a weight of $22.8 \%$. The fourth priority is the rejuvenation with the a weight of $12.45 \%$, and the last priority is the access to the technology (fertilizer) with the a weight of $9.18 \%$.

\section{Land Legality}

The land legality aspect is as one of the requirements for the planters to be able to participate formally in the supply chain of the palm oil. The land certificate is a document that plays a role to access the production inputs such as seeds, fertilizers, and funds.
The weakness of the legality aspect especially the land ownership certificate becomes the constraint of the planters to access the production inputs and the markets. The counseling of the planters is needed to provide an understanding of the importance of the legality aspect. The planters need to be convinced not to transfer the land ownership status easily. The government can also play a role in facilitating the handling of the land certificates. The fulfillment of the legality element in the smallholder plantation supports the sustainability the plantation program.

\section{Finance}

The low productivity leads to the low income, the minimal access to technology, and the difficulty of financing. The problem of financing can be overcome by borrowing from the banks through the Fund Management Agency of Palm Oil Plantation (BPDPKS). The funding from the banks to help finance the investment and the preparation of the rejuvenation is constrained by the credit administration, so that its implementation is not yet optimal.

The institutional strengthening becomes important in overcoming the funding problems in the smallholder plantations. The coaching is needed to direct the planters not to be consumptive, and so the planters can invest. The investment is required to prepare the rejuvenation fund. The Contribution of Plantation Plant Rejuvenation Fund (Idapertabun) which has been implemented in several locations needs to be increased the number and the distribution. The financial institutions for financing are also required to provide the capital lending asssistance with the appropriate interest.

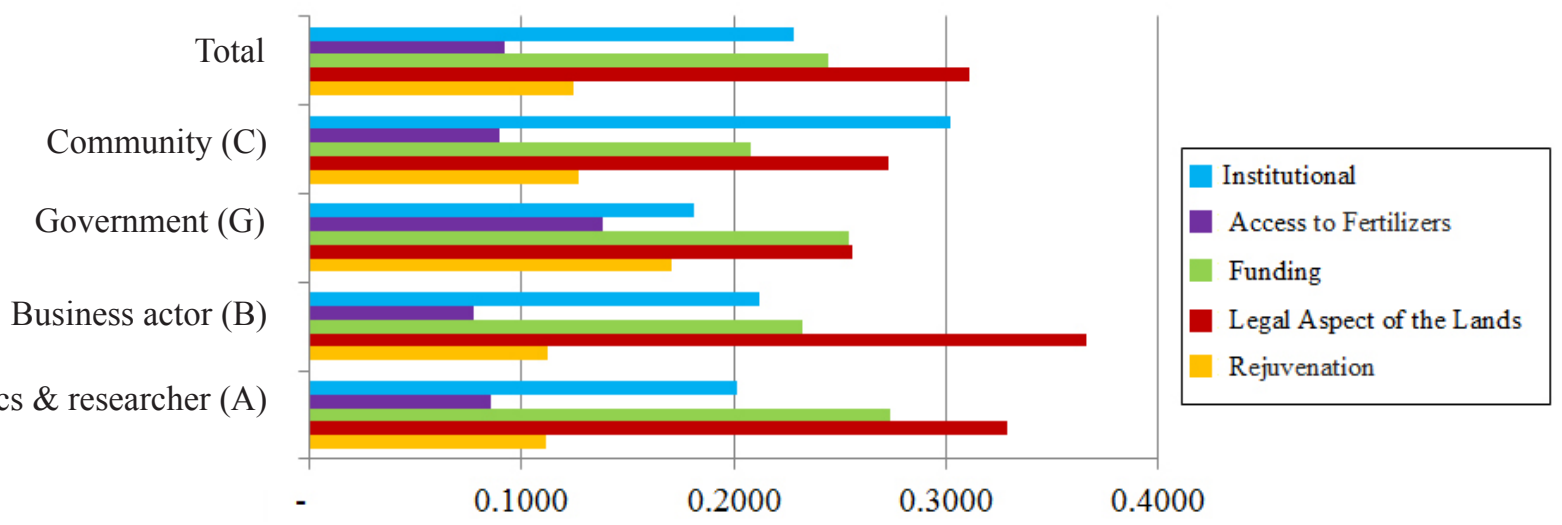

Figure 4. Stakeholder priorities 
Institutional

The institutional role at the planter level is considered not optimal yet. The number and the capacity of the institutional of the planters are still inadequate. Agustira et al. (2015) state that the farmer groups are generally inactive and serve only as of the means of channeling aids or subsidies from the government and the corporation.

The ilnstitutional strengthening can be carried out by the government through improved institutional guidance. The enforcement and the legal compliance in the form of sanctions or incentives that give passions to the participants in behaving according to expectations. The institutional development can be achieved through revitalizing the rules of the organization, improving the structure and function of the organization, and enforcing the rules of the games and establishing business partnerships.

\section{Rejuvenation}

The rejuvenation of the smallholder plantation is needed to improve the productivity that generally has decreased. The main problems of the rejuvenation faced by the smallholder plantation in Indonesia are related with to the financial aspect and the technical culture of the rejuvenation. The fulfillment of the necessities of life during the immature and the amount of investment needed for the rejuvenation process become the inhibition of the rejuvenation.

Theinstitutionalcansetup the rejuvenationfunds through the Contribution of Plantation Plant Rejuvenation Fund (Idapertabun), proved the understanding of the importance of legality, and provide the insight into the proper rejuvenation process. The government can socialize the access to funding from the banks or other financial institutions. Other than that, the government can also facilitate the planters to be able to meet the technical and administrative requirements in obtaining the funds for the rejuvenation.

\section{Access to Fertilizer}

The high fertilizer price becomes an obstacle in the developement of the smallholder plantation, so the government provides the subsidized fertilizer policy. The subsidized fertilizer can be accessed by the planters who are included in the farmer groups by submitteing the Definitive Plan for Group Needs (RDKK).
The result of the research of Anis et al. (2014) shows that the preparation of RDKK in the planter level is still constrained. This is due to the lack of formal education, the lack of understanding of the planters in the organization, and still the lack of guidance and direction from the extension farmers / institutional. The institutional strengthening becomes a factor that plays an important role to open the insight of the planters in doing the fertilization. The government plays a role in giving the extension to the planters about the importance of the fertilizer to the productivity.

\section{Public Policy}

The results of in-depth discussions and interviews with the experts and the software outputs show the public policy that the moratorium policy has the a priority of $23.00 \%$. This policy factor is the lowest factor in the system of policy elements. The law enforcement (weight of $34.62 \%$ ) shows the highest priority in influencing the success of the moratorium policy. Followed by the principles of the sustainability (weight of $34.39 \%$ ), the conflict resolution (weight of $17.96 \%$ ), and the deforestation and the land conversion (weight of $13.03 \%$ ). The consensus of the fourth expert groups is shown in Figure 5.

The Llaw enforcement plays a very important role in the successful implementation of the moratorium policy, because the legal compliance is the foundation for the sustainability of the productsion produced. The principle and the sustainability of the palm oil production in terms of the economic, the social, and the environmental are based on the legal compliance. If the law is enforced, then the sustainability and the conflict resolution can be achieved. Other than that, the law enforcement also plays a role to reduce the deforestation and the land conversion that are claimed to be the major drivers of the greenhouse gas emissions in Indonesia.

\section{Law Enforcement}

The law enforcement of the environment especially the forestry in Indonesia is still weak (Handayani, 2009). The government policy plays an important role in the forest law enforcement. One of the policies issued to reduce the forest destruction is Inpres No 10 of 2011 about the postponement of the new licenses on the primary natural forest and the peat. Although it has been extended for three periods (2011-2017), 
the implementation of the moratorium on the forest conversion delay is considered unsuccessful.

The prevention of the forest destruction can be overcome with the good security from the law enforcement officers, the supporting regulations, and the good community culture on the forest management. Improving the performance of the law enforcement can be done by revamping to enable the law enforcers to have sufficient capacity to enforce the forest law. The weak legal substance can be overcome by renewal and reform efforts on the applicable law such as the reevaluation of the palm oil moratorium for the forestry improvement in Indonesia.

\section{Principle of Sustainability}

International agencies, markets, and wider community demand that the practice of the palm oil plantation industry is conducted sustainably. The development of sustainability is tailored to the concept of three main lines - profit, people, \& planet (Elkington and Zeitz, 2014). The industrial development is based on the economic, social, and environmental sustainability.

The efforts of the government in the sustainability of the palm oil production are indicated by the application of the Indonesian sustainable palm oil plantation guidelines known as Indonesian Sustainable Palm Oil (ISPO). The certification of ISPO, especially on social and environmental aspects, can not be applied optimally. Improved the garden and land governance have not been run as expected. This is shown by the participation of the business actors in Indonesia in the certification. FWI (2017) states than the plantation area that has implemented the system of ISPO is about $13 \%$ (1.5 million ha) of the total area of the palm oil plantation in Indonesia.

The problems of ISPO implementation on the smallholder plantation include several aspects, namely technical, socioeconomic, institutional, and environment. The sustainability of the smallholder plantation can be done by increasing the capacity of the planters. The things that can be done include by building the capacity of the planters to use the certified seeds, improving the training on the good technical culture, improving the access to the rejuvenation, and strengthening the institutional.

\section{Conflict Resolution}

The conflict resolution is an activity undertaken to provide the certainty of tenure (tenurial security) of the lands/natural resources/areas managed by the communityt (FWI, 2017). The tenurial conflict in the palm oil plantation involves three main stakeholders, namely the local community, the planter farmer, and the government. The tenurial issues cause the agrarian structures and relationships generated by the plantation enterprises to be complex.

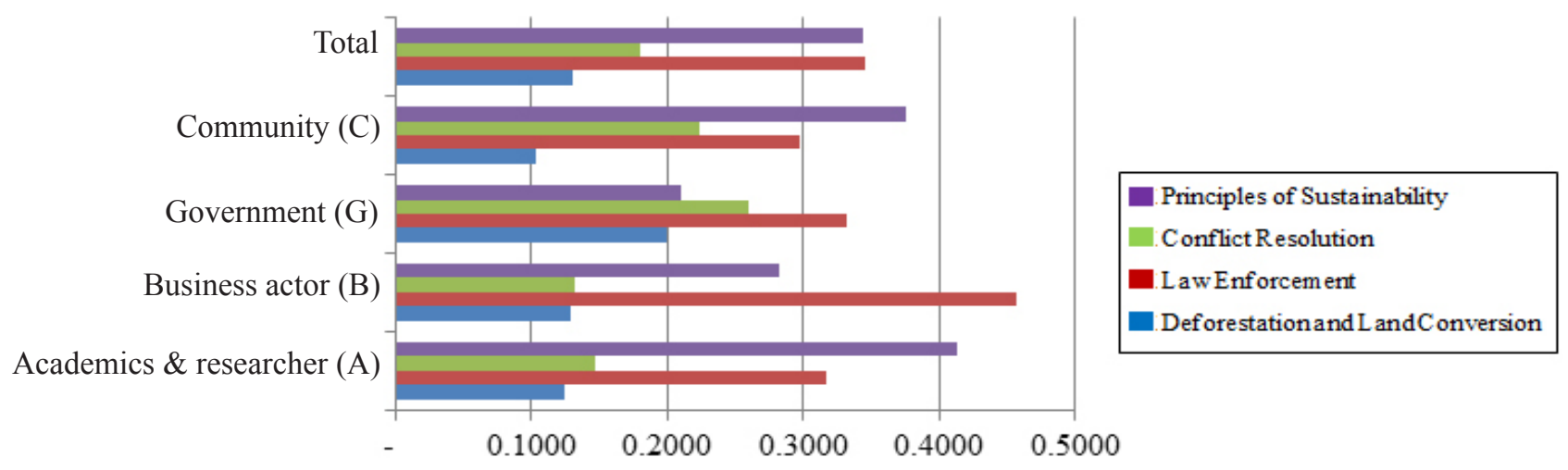

Figure 6. Public policy priorities 
The numbers of emerging conflicts prompt one conflict resolution scheme to resolve the past conflicts and in an effort to minimize the conflict in the future. The conflict between the community and the planter farmer has an effect onaffects the sustainability of the palm oil production. The government has a role to implement the national one- map policy. The realization of a onemap policy that becomes a reference for all stakeholders can provide the legal certainty for the sustainable management of the palm oil plantation. Other than that, the understanding of the importance of the land legality to the community can be done through the counseling and increasing the role of the planter farmer.

\section{Deforestation and Forest Conversion}

The effort to control the deforestation in Indonesia in reducing the greenhouse gas emission is indicated by the enactment of the Presidential Instruction No 10 of 2011. The fact on the ground shows that the implementation of the Presidential Instruction can not reduce the deforestation. The dDeforestation and the forest burning still occur and the new licenses are still being made by the officials in the moratorium area (Murdiyarso et al. 2011). The lack of the understanding of the planter farmer on the ecological issues and the access to heavy equipment cause the small-scale land clearing usually done under the cheapest cost of the land clearing (Pahan, 2017).

The role of the government in law enforcement, monitoring, and providing the information of the forest cover becomes important. The land cover information should be reliable to know which forest concessions are intended for the palm oil. The government can produce spatially and accurately updated and regular updated spatial data on maps and types of forests, land use, land status, and land rights - including the information about the location of the permits already granted - which may easily be accessible to the public through the internet. The degraded land must also be identified, so they can be used for the plantation or other uses through a process that uses best practices in the participatory spatial planning activities.

\section{Level of Understanding of Respondent}

The result of the research shows the coefficient of Kendall of 0.40 which means there are differences of opinions among the experts. This difference of opinion is caused by the difference of viewpoint according to the background of the respective expert. The four groups of the coefficient value of Kendall are shown in Table 4.

Table 4 Kendall coefficient of each group of expert

\begin{tabular}{lcc}
\hline Group of Expert & $\mathrm{N}$ & Kendall Coefficient \\
\hline Academics \& Researcher & 5 & 0.58 \\
Business Actor & 3 & 0.41 \\
Government & 2 & 0.81 \\
Association & 4 & 0.83 \\
Total & 14 & 0.40 \\
\hline
\end{tabular}

The highest level of the expert approval is shown by the government and association experts. Both groups have significant differences of opinions. The government as a group of respondents who support the running of the moratorium policy, while the association is a group of respondents who are less supportive of the moratorium policy.

The high level of approval on the government group shows the government's understanding in of supporting the policy of the moratorium on the conversion of the natural forests and the peatlands. The priority of the moratorium policy by the government expert group yields the weight of $35.37 \%$, the productivity of $28.99 \%$, and the smallholder plantation of $35.64 \%$. The moratorium policy is considered to be one of the ways to improve the forest governance in Indonesia. Improving the forest governance and the smallholder plantation is a dominant issue in increasing the productivity.

The group of respondents indicates that a high level of understanding is shown by the coefficient value of Kendall of 0.83 . The priority of the moratorium policy by the association expert group produces the a weight of $27.64 \%$, the productivity of $47.15 \%$, and the smallholder plantation of $25.22 \%$. This value indicates that according to the association expert group the dominant issue in increasing the productivity is on the improvement of the productivity component itself which consists of the genetic of plant material, the field technical culture, and the quality of oil produced. The low weight of the moratorium policy indicates that the moratorium policy is not the best solution to increase the productivity. 


\section{Managerial Implications}

Increased productivity through the extensification (area expansion) is hampered by the enactment of the moratorium policy according to the Presidential Instruction No 10 of 2011. The moratorium policy aims at improving the Indonesia's forest governance that has not worked properly. The moratorium policy may work if there is a common understanding of the spatial planning among the various stakeholders involved. A single map policy is required to provide the uniform information regarding the forest cover and its designation. This map can be used as a reference for decision making such as the forest management permit (concession). The strong government commitment, the law enforcement supremacy, the improved forest management systems are needed, so that the moratorium policies are not merely impressed to inhibit the growth of the Indonesian palm oil industry. Law enforcement requires adequate human resources and facilities. The lack of numbers and the low quality of human resources, and limited facilities hinder of law enforcement in Indonesia. Human resources training is needed to improve the quality of law enforcement officers. In addition, law enforcement facilities need to be improved.

Increased productivity through the intenstification of the plant (rejuvenation) is hampered by the funding problems. The success of the smallholder plantation rejuvenation program can be achieved, if the sufficient funds are met. The funds are needed both for the implementation of the rejuvenation and for the replacement of new genetic material. The rejuvenation funding can be obtained through the fund of BPDPKS already provided by the government. The fund of BPDPKS are is accessible to the planters by fulfilling the administrative requirements such as the land ownership certificates. Improving the legality aspect of the plantation is needed to ensure the sustainability of the production. The legality aspect can be enhanced by strengthening the institutional role of the smallholder plantation. Counseling for smallholders is needed to provide an understanding of the importance of the legal aspects. Smallholders need to be convinced not to transfer their land ownership status easily. The government can also play a role in facilitating the management of land certificates. Fulfillment of legality in community plantations supports sustainable plantation programs.

\section{CONCLUSIONS AND RECOMMENDATIONS}

\section{Conclusions}

The result of the study indicates that the increased productivity of the palm oil is constrained both through the extensification (area expansion) and the intensification (rejuvenation). The moratorium policy which is expected to improve the forest governance in Indonesia has not been able to run optimally. The six-year moratorium policy (2011-2017) has not been able to address the issue of the forest governance. The various weaknesses of this policy make the conversion in the area of the moratorium continue. The moratorium policy covers the economic growth opportunities through the palm oil industry.

The intensification of the smallholder plantation done through the rejuvenation is hampered by the funding issues. The funds required for the rejuvenation process are not owned by the planters. The funds of BPDPKS can be obtained by the planters by applying for loans through designated banking institutions. The administrative requirements that include the elements of the land legality of the planters are difficult to meet. The weak aspect of the land legality of the planter inhibits the increase of the palm oil productivity. The extensification and intensification barriers of the smallholder plantation threaten the sustainability of the national palm oil production.

The factors that determine the success of the implementation of the moratorium policy include the law enforcement, the sustainability principles, the conflict resolution, and the land deforestation. Improved forest governance through the reductions in the deforestation and the forest conversion can be undertaken, if the forest law enforcement is optimal. The ILegal obedience can be seen from the application of the principle of the sustainability in running a business. The moratorium policy is also expected to be an instrument for the settlement of the forestry conflicts. The conflicts occur mainly on the land tenure aspects between the government, the private companies, and the local community.

The factor that determines the success of the palm oil rejuvenation is funding. The planters can access the funds, if they meet the requirements, especially the legality of the land. The land ownership certificates can be used as the collateral for the banks to obtain 
the funds of BPDPKS. The funds obtained are used the operational processes in the field as well as to obtain genetically the certified plant material.

The strategies that can be implemented to achieve increased productivity that is with the genetic improvement of the plant material, the improvement of the land legality, and the law enforcement moratorium policy. The improvement of the genetic material is done by facilitating the planters' access to the genetic material of the plant with the franchise seeds. The legality improvement can be done by facilitating the making of the land certificate of the planters. The law enforcement by the government can be done to ensure no deforestation in protected areas, so that the moratorium policy does not seem to impede only the expansion of the plantation areas but can also improve the forest governance in Indonesia.

\section{Recommendations}

Areview of the implementation of the moratorium policy is necessary. The moratorium policy being implemented should consider Indonesia's readiness to improve the forest governance. The spatial consolidation and the spatial discussions with the local government and other stakeholders are needed, so that the moratorium policy has a clear direction. The negative and positive impacts need to be taken into account, so that the foreign policy taken does not harm the national interest.

The planter's access to the certified seeds can be improved, if the seed sale rules are updated. The legality requirements of land to get the seeds to need to be reviewed, because the legality of the land planters have has not been optimal. The legality of the land provides a certainty of the managed land not the result of the forest encroachment. The protection of the forest land can be done with a strong commitment and the forest law enforcement from the government. The role of government, smallholders, law enforcement officials and other stakeholders is important to realize a sustainable forest management system. Short-term, medium-term and long-term improvement programs are needed to improve the forest management system.

\section{REFERENCES}

Agustira MA, Amalia R, Nurkhoiry R. 2015. Program sawit untuk rakyat (prowitra) sebagai upaya peningkatan produktivitas, pemberdayaan, keberlanjutan, dan kesejahteraan pekebun kelapa sawit. Medan: Pusat Penelitian Kelapa Sawit.

Alwarittzi W, Nanseki T, Chomei Y. 2015. Analysis of the factors influencing the technical efficiency among oil palm smallholder farmers in Indonesia. Procedia Environmental Science 28(2015):630638.

Anis MS, Efendy L, Muslihat EJ. 2014. Partisipasi anggota kelompok tani dalam penyusunan rencana definitif kelompok/ rencana definiif kebutuhan kelompok. Jurnal Penyuluhan Pertanian 9(1):37-42.

Bappenas. 2010. Nakah kebijakan (policy paper) kebijakan dan strategi dalam meningkatkan nilai tambah dan daya saing kelapa sawit Indonesia secara berkelanjutan dan berkeadilan. Jakarta: Direktorat Pangan dan Pertanian

Chozin MA, Supijatno, Fahmi I, Indrawan D. 2012. Towards an alternative oil palm replanting scheme in Pekanbaru, Riau. Bogor: Round Table Indonesia.

Daemeter Consulting. 2015. Perkembangan kerangka tata kelola kelapa sawit di Indonesia: implikasi untuk sektor kelapa sawit yang bebas dari deforestasi dan bebas dari gambut. Bogor: Daemeter Consulting.

[Ditjendbun] Direktorat Jenderal Perkebunan. 2016. Statistik perkebunan Indonesia 2015-2017 kelapa sawit. Jakarta: Kementerian Pertanian Republik Indonesia.

Dye TR. 2013. Understanding Public Policy. United States: Pearson Education Inc.

Elkington J. and Zeitz J. 2014. Break Through Challenge 10 Ways to Connect Todays Profits with Tomorrow's Bottom Line First Edition. San Francisco: Jossey-Bass.

Euler M, Schwarze S, Siregar H, Qaim M. 2015. Oil palm expansion among smallholder farmer in Sumatera, Indonesia. Goettingen: University of Goettingen.

Fandi, Nugroho A, Niun MA. 2013. Moratorium antara harapan dan kenyataan. Kalimantan Tengah: Wahana Lingkungan Hidup Indonesia.

Fatah A. 2013. Studi kinerja komoditas kelapa sawit di Kalimantan Timur. Jurnal Agrifor 12(2):96- 
109.

[FWI] Forest Watch Indonesia. 2017. Enam tahun ISPO. Jakarta: FWI.

HafifB, Ernawati, Pujiarti Y. 2014. Peluang peningkatan produktivitas kelapa sawit rakyat di provinsi lampung. Jurnal Littri 20(2):100 - 108.

Handayani IGAKR. 2009. Penegakan hukum kehutanan dalam rangka antisipasi dampak climate change di Indonesia. Mimbar Hukum 21(2): 372-379.

Hartl DL, Elizabeth WJ. 1998. Genetics Principles and Analysis. 4th Ed. Canada: Jones and Bartlett Publishers.

Hidayati J, Sukardi, Suryani A, Fauzi AM, Sugiharto. 2015. Optimization of palm oil plantation revitalization in North Sumatera Indonesia. International Journal on Advanced Science Engineering Information Technology 5(6):460468.

Hudori M. 2017. Perbandingan kinerja perkebunan kelapa sawit Indonesia dan Malaysia. Jurnal Citra Widya Edukasi 9(1):93-112.

Hutabarat H. 2016 Nov 26. Dana replanting sawit menganggur. Medan Bisnis. Berita Utama:1(2-3).

[IFC] International Finance Corporation. 2013. Diagnostic study on Indonesian oil palm smallholders. Washington:World Bank Group.

Jaya NS, Hidayati N, Suhadi Z, Rozani A, Rompas A, Nauli M, Jatmiko H, Kurniawan R, Berliani H, Waluyo J et al. 2014. Analisis kebijakan penundaan pemberian izin baru dan penyempurnaan tata kelola hutan alam primer dan lahan gambut. Jakarta: WALHI.

Joyosemito IB, Tokai A, Nakakubo T. 2014. System dynamics model development for evaluation of the moratorium policy on new forest and peatland concessions under bilateral cooperation in Indonesia: palm oil industry sector case study. Journal of Sustainable Energy \& Environment 5(1):1-12.

Kementerian Pertanian. 2016. Pedoman Penilaian Kesesuaian Lahan untuk Komoditas Pertanian Strategis. Jakarta: Balai Besar Litbang Sumberdaya Lahan Pertanian.

Maesaroh SS, Suroso AI, Pahan I. 2018. Moratorium on Oil Palm: Ecological Recovery or Economic Slowdown. Jurnal Aplikasi Manjemen 16(1): 148-155.

Manurung LP, Hutabarat S, Kaswarina S. 2015. Analisis model peremajaan perkebunan kelapa sawit pola plasma di desa meranti Kecamatan
Pangkalan Kuras Kabupaten Pelalawan Provinsi Riau. Jurnal Sorot 10(1):99-113.

Murdiyarso D, Dewi S, Lawrence D, Seymor F. 2011. Indonesia's forest moratorium. Bogor: Cifor.

Nainggolan P. 2012. Kondisi tanaman kelapa sawit yang sudah tua yang layak diremajakan (replanting) pada perkebunan rakyat di Kecamatan Bagan Sinembah Kabupaten Rokan Hilir [tesis]. Pekanbaru: Universitas Riau

Nugroho R. 2003. Kebijakan Publik Formulasi. Implementasi. dan Evaluasi. Jakarta: Elex Media Komputindo.

Otieno NE, Dai X, Barba DD, Bahman A, Smedbol E, Rajeb M, Jaton L. 2016. Palm oil production in Malaysia: an Analytic systems model for balancing economic prosperity. forest conservation and social welfare. Agricultural Sciences 7(1):55-69.

Pahan I. 2017. Panduan Lengkap Kelapa Sawit Manajemen Agribisnis dari Hulu hingga Hilir. Jakarta: Penebar Swadaya.

Papenfus MM. 2011. Investing in oil palm: an analysis of independent smallholder oil palm adoption in Sumatera. Indonesia. Southeast Asia Policy Research Working Paper (15):1-20.

[Pilar] Palangkaraya Institute for Land Use Agricultural Research. 2014. Opportunities for increasing productivity \& profitability of oil palm smallholder farmers in Central Kalimantan. Kalimantan Tengah: Pilar.

[PPKS] Pusat Penelitan Kelapa Sawit. 2016. Product knowledge dari kami untuk kelapa sawit Indonesia. Medan: PPKS.

Rusydiana, AS, Devi A. 2013. Analytic Network Process: Pengantar Teori dan Aplikasi. Bogor: Smart Publishing.

Saaty, TL. 2001. Decision Making with Dependence and Feedback: The Analytic Network Process, RWS Publications, 4922 Ellsworth Avenue, Pittsburgh, PA 15213

Saaty, TL. 2004a. Decision making the Analytic Hierarchy and Network Processes (AHP/ ANP). Journal of Systems Science and Systems Engineering 13:1-35.

Saaty, TL. 2004b. Fundamentals of the analytic network process - Dependence and feedback in decision-making with a single network.Journal of Systems Science and Systems Engineering 13: 129-157.

Soliman T, Lim FKS, Lee JSH, Carrasco LR. 2016. Closing oil palm yield gaps among Indonesian 
smallholders through industry schemes, pruning, weeding and improved seeds. Royal Society Open Science 3: 160292. doi.org/10.1098/ rsos. 160292.

Suroso AI. 2008. Analisis daya saing dan dampak ekonomi regional pengembangan kelapa sawit di Kabupaten Siak [disertasi]. Bogor: Institut Pertanian Bogor.

Susanti E, Hutabarat S, Muwadi D. 2014. Analisis perbandingan alternatif model peremajaan kelapa sawit konvensional dengan underplanting pola perkebunan inti rakyat (pir) di Desa Sei Lambu Makmur Kecamatan Tapung Kabupaten Kampar. Jom Faperta 1(2):1-9.

Susila WR. 2004. Contribution of palm oil industry to economic growth and poverty alleviation in Indonesia. Jurnal Litbang Pertanian 23(3):107114.
Syakir M, Herman M, Pranowo D, Ferry Y. 2015. Pertumbuhan dan produksi tanaman serta pendapatan petani pada model peremajaan kelapa sawit secara bertahap. Jurnal Littri 21(2):69-76.

Vermeulen S, Goad N. 2006. Towards better practice in smallholder palm oil production. London: International Institute for Environment and Development.

World Growth. 2011. Manfaat minyak sawit bagi perekonomian Indonesia. Jakarta: World Growth.

[WRI] World Resources Institute. 2017. Enam tahun memperbaiki tata kelola hutan dan lahan gambut. Jakarta: WRI.

Yusuf AA, Ross EL, Horridge JM, 2018. Indonesia's Moratorium on Palm Oil Expansion from Natural Forests: Economy-Wide Impacts and the Role of International Transfers. Asian Development Review 35(2):85-112. 